\title{
EFFECT OF IRRIGATION WATER QUANTITY AND SOME ANTIOXIDANTS ON YIELD AND SOME PHYSIOLOGICAL TRAITS OF SNAP BEAN GROWN UNDER SANDY SOIL CONDITIONS
}

\author{
M.M.A. Ramadan \\ Hort. Res. Inst.. Agric. Res. Center, Egypt
}

Received: Oct. 27, 2019

Accepted: Dec. 16,2019

\begin{abstract}
A field experiment was carried out during the two successive summer seasons of 2017 and 2018 under sandy soil conditions at EL-Khattara Experimental Farm, Fac. Agric., Zagazig University, to study the effect of irrigation water quantity $(1000,1500$ and $2000 \mathrm{~m} 3 / \mathrm{fed}$.) and foliar spray with some antioxidants (salicylic cid at $200 \mathrm{ppm}$, ascorbic acid at 300 ppm beside control treatments (sprayed with tap water) on growth, plant water relationship, yield and pod quality of snap bean cv, Bronco. The most important findings could be summarized as follows: The interactions between irrigation of snap bean plants at $2000 \mathrm{~m} 3 / \mathrm{fed}$. and spraying with SA at $200 \mathrm{ppm}$ recorded the highest values of dry weight of branches, leaves and total dry weight/ plant, increasing chlorophyll $a, b$ and total chlorophyll $(a+b)$ in leaf tissues, average pod weight, yield / plant and total pods yield/fed., and TSS in green pods. However, the interaction between irrigation water quantity at $2000 \mathrm{m3} / \mathrm{fed}$. and spraying with ascorbic acid at $300 \mathrm{ppm}$ recorded the highest values of total and free water (\%) in leaf tissues and total carbohydrates and Vit. $C$ in green pods in both seasons, whereas interaction treatment between $1000 \mathrm{~m} 3$ water/fed., without antioxidants resulted in the highest values represented bound water and proline amino acid in leaf tissues and total fiber contents in green pods. On the other hand, the interactions between irrigation water quantity at $1000 \mathrm{~m} 3$ water/ fed., and spraying with SA at 200 ppm recorded the highest values of water use efficiency (2.692 and $2.731 \mathrm{~kg}$ green pods/m3 water) in the 1st and 2nd seasons, respectively.
\end{abstract}

Key word: Snap bean, irrigation level, antioxidants, salicylic acid, Vit. C. plant water relationship, yield and water use efficiency

\section{INTRODUCTION}

Snap bean Phaseolus vulgaris, L. is one of the most important member of Fabaceae crops in Egypt, for local consumption and export as an out of vegetable season to European countries. Snap bean also plays an important role for human nutrient as a good source of carbohydrates and protein

The expansion of green bean cultivation is taking place in the new reclaimed lands in Egypt which is characterized as an arid land with very limited sources of irrigation water. Therefore growers have to adopt modern techniques of cultivation to improve water Use Efficiency (WUE). Beans are rapidly growing plants and very sensitive to soil water conditions and quality, so yield can suffer greatly from even brief periods of water shortage. Under such conditions, water stress reduces yield of the crop,. Water management in green bean production is important at all stages of plant development due to its influence on growth yield and yield quality (Smesrud et al., 1997)

Many studies showed that the vegetative growth, total and exportable yield and pod quality of snap bean are greatly affected by irrigation water quantity, Amer et al. (2002), Abdel- 
Mawgoud (2006), Sazen et al. (2008), ElTohamy et al. (2013), El-Noemani et al. (2015), Marzouk et al. (2016), Saleh et al. (2018) and Vidyashree et al. (2018).

Salicylic acid (SA) is a plant growth regulator known as an endogenous marking molecule, which is implicated in different physiological processes, like growth regulation, photosynthesis, stomatal behavior, nutrient uptake and mechanisms of tolerance to abiotic stresses (Hayat et al., 2010).

Spraying plants with SA increased plant growth (El-Shraiy and Hegazi 2009, Thomson et al. 2017 on pea), leaf pigments (Khan et al., 2003 on soybean plant and El-Saadony et al. (2017) on pea, Yield and its components (Amer, 2004, Kmal et al., 2006 on snap bean, Murtaza et al. 2007 pea and Khafaga et al. (2009) and Abbas et al. (2014) on faba bean, Shafeek et al. (2014) and Shokr et al (2014) on snap bean.

Ascorbic acid is an important antioxidant in plants which accumulates in plants as an adaptive mechanism to environmental stress such as water stress, Ascorbic acid regulates stress response as a result of a complex sequence of biochemical reactions such as activation or suppression of key enzymatic reactions, induction of stress responsive proteins synthesis, and the production of various chemical defense compounds and it had a protective role in plant cells from the adverse effects of water stress (Khan et al. 2011). Spraying plants with ascorbic acid recorded the best results for enhancing growth (Burguieres et al., 2007, Azooz and AlFredan, 2009, Younis et al. 2010, Hamaiel et al., 2016 on snap bean, Al-Amry and Mohammed, 2017 and Rasheed, 2018 on broad bean ).

Therefore the aim of this study is to investigate the interactive effect of irrigation quantity and spraying with some antioxidants (salicylic and ascorbic acids) on the growth, yield and pod quality of green bean plants under sandy soil conditions.

\section{MATERIALS AND METHODS}

A field experiment was carried out during the two successive summer seasons of 2017 and 2018 under sandy soil conditions at EL-Khattara Experimental Farm, Fac. Agric., Zagazig University, to study the effect of irrigation water quantity and foliar spray with some antioxidants on growth, plant water relationship, yield and pod quality of snap bean cv, Bronco.

The soil physical and chemical of the used experimental properties site in sandy soil for the two experimental seasons, had 0.14 and $0.15 \%$ organic matter, 8.01 and $7.99 \mathrm{pH}, 2.05$ and $2.16 \mathrm{mmhos} / \mathrm{cm} \mathrm{EC}, 3.93$ and $3.71 \mathrm{ppm}$ available N, 3.92 and 3.97 available $P$ and 12.15 and 13.12 available $K$ in the $1^{\text {st }}$ and $2^{\text {nd }}$ seasons, respectively.

This experiment included 9 treatments, which were the combinations between the three irrigation levels $(1000,1500$ and 2000 $\mathrm{m}^{3} / \mathrm{fed}$.) and the two antioxidants (spraying with salicylic acid at $200 \mathrm{ppm}$, ascorbic acid at $\mathbf{3 0 0} \mathbf{p p m}$, beside control (sprayed with tap water). These treatments were arranged in a split plot design with three replications. Irrigation water quantity was assigned at random in the main plots, while, sub plots were devoted to antioxidants as foliar application .

The experimental unit area was $\mathbf{1 0 . 8}$ $\mathrm{m}^{2}$ and it contains three drippers lines with $6 \mathrm{~m}$ length for each and $60 \mathrm{~cm}$ width, and the distance between drippers was $25 \mathrm{~cm}$, thus each replicate contains 72 drippers. The middle dripper line was used for data collection and the others were used for yield determination. Two rows were left between irrigation levels and $50 \mathrm{~cm}$ was left between plots as a 
guard space to avoid the overlapping of irrigation water.

The seeds of snap bean were obtained from Hort. Res. Inst., Agric. Res. Center, Egypt. Seeds were sown on $12^{\text {th }}$ and $14^{\text {th }}$ March in the $1^{\text {st }}$ and $2^{\text {nd }}$ seasons, respectively in hills $15 \mathrm{~cm}$ apart on one side of dripper, two seeds per hill were grown and then it thinned after completely emergency to one plant/ hill.

All experimental units were received equal amounts of water during germination (50 $\left.\mathrm{m}^{3} / \mathrm{feddan}\right)$. The first irrigation treatments were started after $\mathbf{1 0}$ days from emergence, then the irrigation treatments were started on 22 and $24^{\text {th }}$ March in the $1^{\text {st }}$ and $2^{\text {nd }}$ seasons, respectively of study. The irrigation treatments stopped at 27 and $29^{\text {th }}$ May in $1^{\text {st }}$ and $2^{\text {nd }}$ seasons, respectively. The water was added using water counter and pressure counter. The irrigations were added two days intervals in the morning along plant life.

The amounts of water which added at the different treatments were calculated, expressed in terms of time based on the rate of water flow through the drippers (2L/hr.) at one bar to give such amounts of water presented in schedule (1).

Spraying with salicylic acid and ascorbic acid were applied using hand pressure sprayer three times at 15, 30 and 45 days after sowing, in both seasons.
Nitrogen, phosphorus and potassium were added in the form of ammonium sulphate $\quad(20.5 \quad \% \quad \mathrm{~N}), \quad$ calcium superphosphate $\left(\begin{array}{llll}15.5 & \% & \mathrm{P}_{2} \mathrm{O}_{5}\end{array}\right)$ and potassium sulphate (48 \% $\left.\mathrm{K}_{2} \mathrm{O}\right)$ at the rates of $80 \mathrm{~kg} \mathrm{~N}, 37 \mathrm{~kg} \mathrm{P}_{2} \mathrm{O}_{5}$ and $50 \mathrm{~kg}$ $\mathrm{K}_{2} \mathrm{O}$, respectively. One third of all fertilizers were added at the time of soil preparation with $20 \mathrm{~m}^{3} / \mathrm{fed}$. FYM, but the rest were divided into 10 equal portions and were added through water irrigation system (fertigation) by 3 days intervals, beginning 15 days after sowing. The other normal agricultural treatments for growing snap bean plants were practiced.

\section{Data Recorded}

1. Plant growth: after 60 days from seed sowing different ten plant parts from every experimental unit were oven dried at $70^{\circ} \mathrm{C}$ till constant weight, and the following data were recorded: Dry weight of branches, dry weight of leaves (g) and total dry weight (branches +leaves) (g).

2. Photosynthetic pigments: Disk samples from the fourth upper leaf were obtained after 60 days from sowing in all plots to determined chlorophyll $a$ and $b$ as well as carotenoids in both seasons according to the method described by Wettestein (1957).

Schedule (1): The time (minute) and amounts of applied irrigation water $\left(\mathrm{m}^{3}\right)$ during the growth period of snap bean via dripper

\begin{tabular}{|c|c|c|c|}
\hline $\begin{array}{c}\text { Water quantity } \\
\left(\mathbf{m}^{3} / \text { fed. }\right)\end{array}$ & Irrigation numbers & $\begin{array}{c}\text { Time needed } / \text { in } \\
\text { every irrigation } \\
(\text { min. })\end{array}$ & $\begin{array}{c}\text { Water supply I } \\
\text { irrigation }\left(\mathbf{m}^{3} / \text { fed. }\right)\end{array}$ \\
\hline 1000 & 32 & 32.5 & 31.25 \\
\hline 1500 & 32 & 48.0 & 46.87 \\
\hline 2000 & 32 & 65.0 & 62.50 \\
\hline
\end{tabular}


3. Plant water relations: Total, free and bound water in the fourth upper leaf of snap bean plants were determined for every experimental unit at 60 days after sowing, in both seasons, according to the method described by Gosev (1960).

4. Proline amino acid content: was determined in the leaves at 60 days after sowing in both seasons of study according to Bates (1973).

5. Pod yield and its components: Green pods of each plot were harvested at the proper maturity stage ( at 75 days after sowing), counted and weighted in each harvest and yield I plant and total fresh pod yield (ton /fed.) were determined. Ten plants were randomly marked from each plot for determining the number of pods/plant. Twenty pods were randomly chosen from each treatment to determine; average weight of pod (gm) and pod length (cm).

6.Water use efficiency (WUE)

It was calculated according to equation of Begg and Turner (1976) as follows

Water use efficiency $=$

$$
\frac{\text { Yield }(\mathrm{kg} / \mathrm{fed})}{\text { Water quantity }\left(\mathrm{m}^{3} / \mathrm{fed}\right)}=\mathrm{kg} / \mathrm{m}^{3}
$$

7. Pod quality; Randomly samples of pods from each treatment were taken to assay the following characters: Total soluble solids contents (TSS) as brix ${ }^{\circ}$ : total soluble solids content using the hand refractometer. Total carbohydrate (\%): was determined in pods dry matter according to the method described by Dubois et al. (1956). Pod total $\mathrm{N} \%$ was determined and a factor of 6.25 was used for conversion of total protein percentage (Kelly and Bliss, 1975). Vitamin C (mg/100gf.w.) was determined in juice using 2, 6 dicholorophenol indophenol dye according to A.O.A.C (1990). Crude fibers were determined as percentage according to Maynard (1970).

\section{Statistical analysis:}

The data of this experiment was subjected to proper statistical analysis of variance according to Snedecor and Cochran (1980) and the differences among treatments were compared using LSD at 0.05 level.

\section{RESULTS AND DISCUSSION}

\section{Plant Growth}

Quantity of irrigation water resulted in a significant alternation in dry weight of branches, leaves and total dry weight/ plant in the two grown seasons (Table 1). Irrigation water up to the highest level (2000 $\mathrm{m}^{3} / \mathrm{fed}$.), recorded the highest values of dry weight of branches, leaves and total dry weight/ plant, while irrigation water quantity at $1000 \mathrm{~m}^{3} / \mathrm{fed}$. recorded the lowest values if the pervious characters, in both seasons.

The relative increases in total dry weight were about (19.21 and $16.71 \%$ ) for $1500 \mathrm{~m}^{3} / \mathrm{fed}$., and (47.26 and $\left.56.08 \%\right)$ for $2000 \mathrm{~m}^{3}$ water/fed., over than treatment (1000 $\mathrm{m}^{3}$ water/fed.) in the $1^{\text {st }}$ and $2^{\text {nd }}$ seasons, respectively.

The decline in branches and leaves dry weights in response to drought might be due to the reduction in cell elongation resulting from the inhibiting effect of water shortage on growth promoting hormones which, in turn, led to a decrease in each of cell turgor, cell volume and eventually cell growth (Banon et al., 2006).

These results are harmony with those reported with Amer et al. (2002), AbdelMawgoud (2007) and Sazen et al. (2008) on snap bean. They found that increasing water quantity increased dry weight of snap bean plants. 
Table (1). Effect of irrigation water quantity and some antioxidants foliar application on dry weight of different plant organs of snap bean at 60 days after sowing during 2017 and 2018 seasons

\begin{tabular}{|c|c|c|c|c|c|c|}
\hline \multirow[t]{2}{*}{ Characters } & \multicolumn{2}{|c|}{$\begin{array}{l}\text { Dry weight of } \\
\text { branches (g) }\end{array}$} & \multicolumn{2}{|c|}{$\begin{array}{l}\text { Dry weight of } \\
\text { leaves }(g)\end{array}$} & \multicolumn{2}{|c|}{$\begin{array}{c}\text { Total dry } \\
\text { weight (g) }\end{array}$} \\
\hline & $\begin{array}{c}2017 \\
\text { season }\end{array}$ & $\begin{array}{c}2018 \\
\text { season }\end{array}$ & $\begin{array}{c}2017 \\
\text { season }\end{array}$ & $\begin{array}{c}2018 \\
\text { season }\end{array}$ & $\begin{array}{c}2017 \\
\text { season }\end{array}$ & $\begin{array}{l}2018 \\
\text { season }\end{array}$ \\
\hline & \multicolumn{6}{|c|}{ Effect of irrigation water quantity } \\
\hline 1000 (m³/fed.) & 4.44 & 4.11 & 5.97 & 5.99 & 10.41 & 10.11 \\
\hline 1500 (m³/fed.) & 4.93 & 4.97 & 7.48 & 6.83 & 12.41 & 11.80 \\
\hline 2000 (m³/fed.) & 6.58 & 6.45 & 8.75 & 9.33 & 15.33 & 15.78 \\
\hline \multirow[t]{2}{*}{ LSD at 0.05 level } & 0.17 & 0.43 & 0.57 & 0.20 & 0.48 & 0.58 \\
\hline & \multicolumn{6}{|c|}{ Effect of some antioxidants } \\
\hline Unsprayed ( control) & 4.75 & 4.46 & 6.53 & 6.46 & 11.28 & 10.91 \\
\hline SA at $200 \mathrm{ppm}$ & 5.89 & 5.90 & 8.20 & 8.38 & 14.09 & 14.27 \\
\hline Vit. C at 300 ppm & 5.32 & 5.18 & 7.48 & 7.32 & 12.79 & 12.50 \\
\hline LSD at 0.05 level & 0.14 & 0.34 & 0.44 & 0.16 & 0.38 & 0.46 \\
\hline
\end{tabular}

Concerning the effect of foliar application of antioxidants, it was quite clear from data in Table 1 that, spraying snap bean plants with salicylic acid (SA) or ascorbic acid (Vit. C) exerted the highest effect for enhancing dry weight of branches and leaves as well as total dry weight/ plant as compared to unsprayed plants, however, where spraying plants with SA at $200 \mathrm{ppm}$ recorded the highest values of different organs dry weight or total dry weight I plant, in both seasons.

The relative increases in total dry weight were about (24.91 and $30.79 \%$ ) for SA treatment and (13.38 and $14.57 \%)$ for Vit. C treatment over than unsprayed plants in the $1^{\text {st }}$ and $2^{\text {nd }}$ seasons, respectively.

Salicylic acid (SA) is a plant growth regulator known as an endogenous marking molecule, which is implicated in different physiological processes, like tolerance to abiotic stresses (Hayat et al., 2010). Ascorbic acid is an important antioxidant in plants which accumulates in plants as an adaptive mechanism to environmental stress such as water stress.

The effect of ascorbic acid on snap bean growth can be discussed on the ground that ascorbic acid seems to enhance biosynthesis of soluble sugars and carbohydrates which are vital steps in stepping up plant tissues (Rady, 2006). Moreover, ascorbic acid has auxinic effect and protects plant cells against free radicals that are responsible for plant senescence (Elade, 1992) and has effectual role in many metabolic and physiological processes (Shadded et al., 1990).

Results are in agreement with ElShraiy and Hegazi (2009) and Thomson et al. (2017) on pea as for the effect of SA and Burguieres et al. (2007) with respect to Vit. C

As for the interactions between water quantity and spraying with antioxidants as foliar application, it is evident from data presented in Table 2 that the interactions treatment between irrigation water quantity at $2000 \mathrm{~m}^{3} /$ fed., with SA 
application recorded the highest values of dry weight of branches, leaves and total dry weight/ plant in both seasons. While the lowest values were obtained with the interactions between 1000 $\mathrm{m}^{3} / \mathrm{fed}$. irrigation water and unsprayed plants in both seasons.

The relative increases in total dry weight/ plant due to the interactions between $2000 \mathrm{~m}^{3}$ waterl fed., and spraying with SA were about 81.36 and $102.12 \%$ over irrigation water quantity at $1000 \mathrm{~m}^{3} / \mathrm{fed}$., without SA or Vit. C in the $1^{\text {st }}$ and $2^{\text {nd }}$ seasons, respectively.

\section{Photosynthetic Pigments}

The current data in Table 3 show that irrigating snap bean plants with 2000 $\mathrm{m}^{3} / \mathrm{fed}$., recorded the highest values of chlorophyll a, b and total chlorophyll and lowest values of carotenoides in leaf tissues in both seasons. On the other hand, snap bean plants grown under water stress $\left(1000 \mathrm{~m}^{3} / \mathrm{fed}\right.$.) recorded the lowest values of chlorophylls and highest values of carotenoides. The reduction in chlorophyll content under water stress implies a lowered capacity for light harvesting. Since the production of reactive oxygen species is mainly driven by excess energy absorption in the photosynthetic apparatus, this might be avoided by degrading the absorbing pigments (Herbinger et al., 2002). These results agree with El-Noemani et al. (2015) on snap bean.

It is clear from the data in Table 3 that the spraying snap been plants with SA or Vit. C of exerted a marked significant effect on chlorophyll $a, b$ and total chlorophyll $(a+b)$ than unsprayed plants in both seasons. However sprayed plants with $\mathrm{Sa}$ recorded the maximum concentration of chlorophyll $a, b$ and total chlorophyll in leaf tissues of snap bean, followed by Vit. $C$ in both seasons. While spraying with antioxidants did not reflect any significant effect on carotenoides in both seasons.

Table (2). Effect of interaction between irrigation water quantity and some antioxidants foliar application on dry weight of different plant organs of snap bean at 60 days after sowing during 2017 and 2018 seasons

\begin{tabular}{|c|c|c|c|c|c|c|c|}
\hline \multirow{2}{*}{\multicolumn{2}{|c|}{ Treatments }} & \multicolumn{2}{|c|}{$\begin{array}{l}\text { Dry weight of } \\
\text { branches (g) }\end{array}$} & \multicolumn{2}{|c|}{$\begin{array}{l}\text { Dry weight of } \\
\text { leaves }(g)\end{array}$} & \multicolumn{2}{|c|}{$\begin{array}{l}\text { Total dry } \\
\text { weight (g) }\end{array}$} \\
\hline & & \multirow{2}{*}{$\begin{array}{c}\begin{array}{c}2017 \\
\text { season }\end{array} \\
3.94\end{array}$} & \multirow{2}{*}{$\begin{array}{c}\begin{array}{c}2018 \\
\text { season }\end{array} \\
3.56\end{array}$} & \multirow{2}{*}{$\begin{array}{c}\begin{array}{c}2017 \\
\text { season }\end{array} \\
5.13\end{array}$} & \multirow{2}{*}{$\begin{array}{c}\begin{array}{c}2018 \\
\text { season }\end{array} \\
5.37\end{array}$} & \multirow{2}{*}{$\begin{array}{c}\begin{array}{c}2017 \\
\text { season }\end{array} \\
9.07\end{array}$} & \multirow{2}{*}{$\begin{array}{c}\begin{array}{c}2018 \\
\text { season }\end{array} \\
8.93\end{array}$} \\
\hline \multirow{3}{*}{$\begin{array}{l}1000 \\
\mathrm{~m}^{3} / \mathrm{fed} .\end{array}$} & Unsprayed (control) & & & & & & \\
\hline & SA at $200 \mathrm{ppm}$ & 4.97 & 4.85 & 6.70 & 6.73 & 11.67 & 11.58 \\
\hline & Vit. C at 300 ppm & 4.41 & 3.93 & 6.09 & 5.88 & 10.50 & 9.81 \\
\hline \multirow{3}{*}{$\begin{array}{l}1500 \\
\mathrm{~m}^{3} / \mathrm{fed} .\end{array}$} & Unsprayed (control) & 4.27 & 4.27 & 6.37 & 6.08 & 10.64 & 10.35 \\
\hline & SA at $200 \mathrm{ppm}$ & 5.57 & 5.72 & 8.58 & 7.47 & 14.15 & 13.19 \\
\hline & Vit. C at 300 ppm & 4.96 & 4.91 & 7.49 & 6.95 & 12.45 & 11.86 \\
\hline \multirow{3}{*}{$\begin{array}{l}2000 \\
\mathrm{~m}^{3} / \mathrm{fed} .\end{array}$} & Unsprayed (control) & 6.03 & 5.54 & 8.09 & 7.92 & 14.12 & 13.46 \\
\hline & SA at $200 \mathrm{ppm}$ & 7.14 & 7.12 & 9.31 & 10.93 & 16.45 & 18.05 \\
\hline & Vit. C at 300 ppm & 6.58 & 6.69 & 8.85 & 9.14 & 15.43 & 15.83 \\
\hline \multicolumn{2}{|c|}{ LSD at 0.05 level } & 0.24 & 0.59 & 0.77 & 0.27 & 0.66 & 0.80 \\
\hline
\end{tabular}


Table (3). Effect of irrigation water quantity and some antioxidants foliar application on leaf pigments of snap bean leaves ( $\mathrm{mg} / \mathrm{g} \mathrm{DW}$ ) at 60 days after sowing during 2017 and 2018 seasons

\begin{tabular}{|c|c|c|c|c|c|c|c|c|}
\hline \multirow{3}{*}{ Characters } & \multicolumn{2}{|c|}{ Chlorophyll a } & \multicolumn{2}{|c|}{ Chlorophyll b } & \multicolumn{2}{|c|}{ Chlorophyll $a+b$} & \multicolumn{2}{|c|}{ Carotenoides } \\
\hline & $\begin{array}{c}2017 \\
\text { season }\end{array}$ & $\begin{array}{l}2018 \\
\text { season }\end{array}$ & $\begin{array}{l}2017 \\
\text { season }\end{array}$ & $\begin{array}{c}2018 \\
\text { season }\end{array}$ & $\begin{array}{c}2017 \\
\text { season }\end{array}$ & $\begin{array}{l}2018 \\
\text { season }\end{array}$ & $\begin{array}{c}2017 \\
\text { season }\end{array}$ & $\begin{array}{l}2018 \\
\text { season }\end{array}$ \\
\hline & \multicolumn{8}{|c|}{ Effect of irrigation water quantity } \\
\hline $\begin{array}{c}1000 \\
\text { (mlfed.) }\end{array}$ & 2.51 & 2.56 & 1.41 & 1.41 & 3.93 & 3.97 & 2.72 & 2.28 \\
\hline $\begin{array}{c}1500 \\
\text { ( } \mathrm{m}^{3} / \text { fed.) }\end{array}$ & 2.80 & 2.91 & 1.51 & 1.67 & 4.31 & 4.58 & 2.15 & 2.04 \\
\hline $\begin{array}{c}2000 \\
\text { ( } \mathrm{m}^{3} / \text { fed.) }\end{array}$ & 3.11 & 3.21 & 1.79 & 1.84 & 4.89 & 5.05 & 2.19 & 2.07 \\
\hline \multirow[t]{2}{*}{$\begin{array}{c}\text { LSD at } 0.05 \\
\text { level }\end{array}$} & 0.18 & 0.14 & 0.21 & 0.08 & 0.19 & 0.16 & 0.10 & 0.12 \\
\hline & \multicolumn{8}{|c|}{ Effect of some antioxidants } \\
\hline $\begin{array}{l}\text { Unsprayed } \\
\text { ( control) }\end{array}$ & 2.39 & 2.57 & 1.45 & 1.50 & 3.84 & 4.07 & 2.21 & 2.14 \\
\hline $\begin{array}{l}\text { SA at } 200 \\
\text { ppm }\end{array}$ & 3.13 & 3.17 & 1.63 & 1.73 & 4.76 & 4.90 & 2.48 & 2.11 \\
\hline $\begin{array}{l}\text { Vit. C at } \\
300 \mathrm{ppm}\end{array}$ & 2.90 & 2.93 & 1.63 & 1.69 & 4.53 & 4.63 & 2.36 & 2.14 \\
\hline $\begin{array}{l}\text { LSD at } 0.05 \\
\text { level }\end{array}$ & 0.14 & 0.11 & 0.17 & 0.06 & 0.15 & 0.12 & NS & NS \\
\hline
\end{tabular}

SA has direct involvement in plant growth, thermogenesis, flower induction and uptake of ions. It affects ethylene biosynthesis, stomata movement and also reverses the effects of $A B A$ on leaf abscission. It has an important role in enhancement the level of chlorophyll and carotenoid pigments, photosynthetic rate and modifying the activity of some important enzymes (Abdel-Ati et al., 2000).

Ascorbic acid a good scavenger of activated oxygen as $\mathrm{O} 2, \mathrm{OH}, 102$ and reducing hydrogen peroxide ( $\mathrm{H} 2 \mathrm{O} 2)$ to water via ascorbate peroxidase reaction (Noctor and Foyer, 1998), as well as, enhancing the accumulation of chlorophyll and delay senescence (Novabour et al., 2003). These results are similar to that recorded by Khan et al. (2003) on soybean plant and El-Saadony et al. (2017) on pea for salicylic acid and Hamaiel et al. (2016) on snap bean for ascorbic acid.

Concerning the interactions between water quantity and spraying with antioxidants as foliar application, it is evident from data presented in Table 4 that the interaction treatments between irrigation water quantity of $2000 \mathrm{~m}^{3} /$ fed. and SA application gave the best results for increasing chlorophyll $a, b$ and total chlorophyll in both seasons. The interaction between $1000 \mathrm{~m}^{3} / \mathrm{fed}$. irrigation water and foliar spraying with SA gave the highest concentration of carotenoides in both seasons. 
Table (4). Effect of interaction between irrigation water quantity and some antioxidants foliar application on leaf pigments of snap bean leaves (mg/g DW) at 60 days after sowing during 2017 and 2018 seasons.

\begin{tabular}{|c|c|c|c|c|c|c|c|c|c|}
\hline \multirow{2}{*}{\multicolumn{2}{|c|}{ Treatments }} & \multicolumn{2}{|c|}{ Chlorophyll a } & \multicolumn{2}{|c|}{ Chlorophyll b } & \multicolumn{2}{|c|}{$\begin{array}{c}\text { Chlorophyll } \\
a+b\end{array}$} & \multicolumn{2}{|c|}{ Carotenoides } \\
\hline & & \multirow{2}{*}{\begin{tabular}{|c|}
$\begin{array}{c}2017 \\
\text { season }\end{array}$ \\
2.02 \\
\end{tabular}} & \multirow{2}{*}{\begin{tabular}{|c|}
$\begin{array}{c}2018 \\
\text { season }\end{array}$ \\
2.17 \\
\end{tabular}} & \multirow{2}{*}{\begin{tabular}{|c|}
$\begin{array}{c}2017 \\
\text { season }\end{array}$ \\
1.30 \\
\end{tabular}} & \multirow{2}{*}{\begin{tabular}{|c|}
$\begin{array}{c}2018 \\
\text { season }\end{array}$ \\
1.20 \\
\end{tabular}} & \multirow{2}{*}{\begin{tabular}{|c|}
$\begin{array}{c}2017 \\
\text { season }\end{array}$ \\
3.32 \\
\end{tabular}} & \multirow{2}{*}{\begin{tabular}{|c|}
$\begin{array}{c}2018 \\
\text { season }\end{array}$ \\
3.37 \\
\end{tabular}} & \multirow{2}{*}{\begin{tabular}{|c|}
$\begin{array}{c}2017 \\
\text { season }\end{array}$ \\
2.15 \\
\end{tabular}} & \multirow{2}{*}{\begin{tabular}{|c|}
$\begin{array}{c}2018 \\
\text { season }\end{array}$ \\
2.32 \\
\end{tabular}} \\
\hline \multirow{3}{*}{$\begin{array}{l}1000 \\
\mathrm{~m}^{3} / \mathrm{fed} .\end{array}$} & \begin{tabular}{|l|} 
Unsprayed \\
( control)
\end{tabular} & & & & & & & & \\
\hline & $\begin{array}{l}\text { SA at } 200 \\
\text { ppm }\end{array}$ & 2.94 & 3.04 & 1.50 & 1.61 & 4.44 & 4.65 & 3.12 & 2.28 \\
\hline & $\begin{array}{l}\text { Vit. C at } 300 \\
\text { ppm }\end{array}$ & 2.58 & 2.46 & 1.44 & 1.43 & 4.02 & 3.89 & 2.90 & 2.25 \\
\hline \multirow{3}{*}{$\begin{array}{l}1500 \\
\mathrm{~m}^{3} / \mathrm{fed} .\end{array}$} & $\begin{array}{l}\text { Unsprayed } \\
\text { ( control) }\end{array}$ & 2.43 & 2.56 & 1.43 & 1.52 & 3.86 & 4.08 & 2.24 & 2.06 \\
\hline & $\begin{array}{l}\text { SA at } 200 \\
\text { ppm }\end{array}$ & 3.07 & 3.17 & 1.53 & 1.73 & 4.6 & 4.9 & 2.11 & 2.04 \\
\hline & $\begin{array}{l}\text { Vit. C at } 300 \\
\text { ppm }\end{array}$ & 2.90 & 3.00 & 1.58 & 1.76 & 4.48 & 4.76 & 2.09 & 2.02 \\
\hline \multirow{3}{*}{$\begin{array}{l}2000 \\
\mathrm{~m}^{3} / \mathrm{fed} .\end{array}$} & $\begin{array}{l}\text { Unsprayed } \\
\text { (control) }\end{array}$ & 2.72 & 2.98 & 1.62 & 1.77 & 4.34 & 4.75 & 2.25 & 2.05 \\
\hline & $\begin{array}{l}\text { SA at } 200 \\
\text { ppm }\end{array}$ & 3.38 & 3.30 & 1.86 & 1.86 & 5.24 & 5.16 & 2.21 & 2.01 \\
\hline & $\begin{array}{l}\text { Vit. C at } 300 \\
\text { ppm }\end{array}$ & 3.22 & 3.34 & 1.88 & 1.89 & 5.1 & 5.23 & 2.10 & 2.16 \\
\hline \multicolumn{2}{|c|}{ LSD at 0.05 level } & 0.25 & 0.20 & 0.29 & 0.11 & 0.26 & 0.21 & 0.14 & 0.07 \\
\hline
\end{tabular}

\section{Plant Water Relations}

The obtained data in Table 5 show that total and free water (\%) of snap bean leaf tissue significantly increased with increasing irrigation water quantity. Water quantity of $2000 \mathrm{~m}^{3} / \mathrm{fed}$., increased total and free water (\%) in leaf tissues, whereas $1000 \mathrm{~m}^{3}$ water quantity/fed., increased bound water, and proline amino acid concentration in leaf tissues of snap bean plants in both seasons.

The increasing in bound water and the reduction in free water under water stress were mainly due to the increases in osmotic pressure resulted from the conversion of starch into soluble carbohydrates as indicated by Lancher (1993). Also, Barker et al. (1993) found that leaf proline concentration averaged 20 times greater in the stressed plant compared to well watered plants. In this regard, Stewart (1977) reported that the conversion of proline to glutamic acid and hence to other soluble compounds proceeds readily in turgid leaves and it is stimulated by higher concentrations of proline. This suggests that proline oxidation could function as a control mechanism for maintaining low cellular levels of proline in turgid tissues. In water stressed, however, proline oxidation is reduced to negligible rates. It seems likely that inhibition of proline oxidation is necessary in maintaining high levels of proline found in stressed levels. These results were found to be agree with El-Tayeb (2006) who found that free amino acids including proline were significantly accumulated in response to drought stress. 
Table (5): Effect of irrigation water quantity, some antioxidants foliar application on plant water relationship and proline amino acid of snap bean at 60 days after sowing during 2017 and 2018 seasons

\begin{tabular}{|c|c|c|c|c|c|c|c|c|}
\hline \multirow{3}{*}{ Characters } & \multicolumn{2}{|c|}{$\begin{array}{l}\text { Total water } \\
\text { (\%) }\end{array}$} & \multicolumn{2}{|c|}{ Free water (\%) } & \multicolumn{2}{|c|}{$\begin{array}{l}\text { Bound water } \\
\text { (\%) }\end{array}$} & \multicolumn{2}{|c|}{$\begin{array}{c}\text { Proline amino } \\
\text { acid } \\
(\mathrm{mg} / 100 \mathrm{~g} \mathrm{DW})\end{array}$} \\
\hline & $\begin{array}{c}2017 \\
\text { season }\end{array}$ & $\begin{array}{c}2018 \\
\text { season }\end{array}$ & $\begin{array}{c}2017 \\
\text { season }\end{array}$ & $\begin{array}{c}2018 \\
\text { season }\end{array}$ & $\begin{array}{c}2017 \\
\text { season }\end{array}$ & $\begin{array}{c}2018 \\
\text { season }\end{array}$ & $\begin{array}{c}2017 \\
\text { season }\end{array}$ & $\begin{array}{l}2018 \\
\text { season }\end{array}$ \\
\hline & \multicolumn{8}{|c|}{ Effect of irrigation water quantity } \\
\hline $\begin{array}{c}1000 \\
\left(\mathrm{~m}^{3} / \text { fed. }\right)\end{array}$ & 82.69 & 81.07 & 57.15 & 49.34 & 25.54 & 31.73 & 177.55 & 168.40 \\
\hline $\begin{array}{c}1500 \\
\text { ( } \mathrm{m}^{3} / \text { ffed.) }\end{array}$ & 82.98 & 83.03 & 59.84 & 53.11 & 23.14 & 29.92 & 137.28 & 135.25 \\
\hline $\begin{array}{c}2000 \\
\left(\mathrm{~m}^{3} / \mathrm{fed} .\right)\end{array}$ & 83.41 & 83.58 & 62.80 & 56.54 & 20.61 & 27.04 & 97.59 & 95.51 \\
\hline \multirow[t]{2}{*}{$\begin{array}{c}\text { LSD at } 0.05 \\
\text { level }\end{array}$} & 0.58 & 0.87 & 0.59 & 0.47 & 0.51 & 0.57 & 2.18 & 2.61 \\
\hline & \multicolumn{8}{|c|}{ Effect of some antioxidants } \\
\hline $\begin{array}{l}\text { Unsprayed } \\
\text { ( control) }\end{array}$ & 82.54 & 82.02 & 57.20 & 51.41 & 25.34 & 30.61 & 151.22 & 143.51 \\
\hline $\begin{array}{l}\text { SA at } 200 \\
\text { ppm }\end{array}$ & 82.91 & 82.64 & 61.21 & 52.88 & 21.70 & 29.76 & 137.04 & 131.00 \\
\hline $\begin{array}{l}\text { Vit. C at } \\
300 \mathrm{ppm}\end{array}$ & 83.63 & 83.01 & 61.38 & 54.69 & 22.25 & 28.32 & 124.16 & 124.65 \\
\hline $\begin{array}{l}\text { LSD at } 0.05 \\
\text { level }\end{array}$ & 0.48 & 0.68 & 0.46 & 0.37 & 0.40 & 0.44 & 1.77 & 2.05 \\
\hline
\end{tabular}

Obtained data in Table 5 show that spraying plants with SA or Vit.C significantly affected total and free water in snap bean leaf tissues than unsprayed treatment in both seasons, where spraying snap bean plants with SA increased total water and free water, meanwhile it decrease bound water and proline amino acid in leaf tissues. Unsprayed plants increased bound water and proline amino acid in both seasons. Salicylic acid (SA) is a plant growth regulator known as an mechanisms of tolerance to abiotic stresses (Hayat et al., 2010).

Presented data in Table 6 show that, the interaction between water irrigation quantity of $2000 \mathrm{~m}^{3} / \mathrm{fed}$., and spraying snap bean plants with antioxidants, i.e., SA or Vit. C were the superior treatments for increasing total and free water (\%) in leaf tissues, whereas interaction treatment between $1000 \mathrm{~m}^{3}$ waterlfed. and unsprayed plants with antioxidants resulted in the highest values of bound water and proline amino acid and lowest values of total and free water in leaf tissues. Salicylic acid as anti-stress substance may enhance the plant tolerance to environmental stresses (Sreenivasulu et al., 2000).

\section{Yield and its Components and Water Use Efficiency (WUE)}

Data presented in Table 7 show that, average pod weight, number of pods/ plant, yield/ plant and total yield per fed., as well as water use efficiency significantly affected by irrigation treatments in both seasons. 
Table (6): Effect of interaction between irrigation water quantity and some antioxidants foliar application on plant water relationship and proline amino acid of snap bean at 60 days after sowing during 2017 and 2018 seasons

\begin{tabular}{|c|c|c|c|c|c|c|c|c|c|}
\hline \multirow{2}{*}{\multicolumn{2}{|c|}{$x$}} & \multicolumn{2}{|c|}{$\begin{array}{c}\text { Total water } \\
\text { (\%) }\end{array}$} & \multicolumn{2}{|c|}{ Free water (\%) } & \multicolumn{2}{|c|}{$\begin{array}{c}\text { Bound water } \\
\text { (\%) }\end{array}$} & \multicolumn{2}{|c|}{$\begin{array}{c}\text { Proline amino } \\
\text { acid } \\
(\mathrm{mg} / 100 \mathrm{~g} \mathrm{DW})\end{array}$} \\
\hline & & 2017 & & 2017 & 201 & 2017 & & 2017 & 2018 \\
\hline \multirow{3}{*}{$\begin{array}{l}1000 \\
\mathrm{~m}^{3} / \mathrm{fed} .\end{array}$} & $\begin{array}{l}\text { Unsprayed } \\
\text { ( control) }\end{array}$ & 82.07 & 80.41 & 55.88 & 48.10 & 26.19 & 32.31 & \begin{tabular}{|l}
195.87 \\
\end{tabular} & 180.87 \\
\hline & $\begin{array}{l}\text { SA at } 200 \\
\text { ppm }\end{array}$ & 82.64 & 81.00 & 56.97 & 49.10 & 25.67 & 31.9 & 175.61 & 169.13 \\
\hline & $\begin{array}{l}\text { Vit. C at } 300 \\
\text { ppm }\end{array}$ & 83.35 & 81.80 & 58.59 & 50.81 & 24.76 & 30.99 & 161.17 & 155.21 \\
\hline \multirow{3}{*}{$\begin{array}{l}1500 \\
\mathrm{~m}^{3} / \text { fed. }\end{array}$} & $\begin{array}{l}\text { Unsprayed } \\
\text { ( control) }\end{array}$ & 82.58 & 82.17 & 56.48 & 51.87 & 26.1 & 0.3 & 149.42 & 146.40 \\
\hline & $\begin{array}{l}\text { SA at } 200 \\
\text { ppm }\end{array}$ & 82.36 & 83.46 & 61.68 & 52.75 & 20.68 & 30.71 & 138.78 & 131.57 \\
\hline & $\begin{array}{l}\text { Vit. C at } 300 \\
\text { ppm }\end{array}$ & 84.00 & 83.45 & 61.37 & 54.71 & 22.63 & 28.74 & 123.63 & 127.79 \\
\hline \multirow{3}{*}{$\begin{array}{l}2000 \\
\mathrm{~m}^{3} / \mathrm{fed} .\end{array}$} & $\begin{array}{l}\text { Unsprayed } \\
\text { ( control) }\end{array}$ & 82.96 & 83.49 & 59.24 & 54.26 & 23.72 & 29.23 & 108.37 & 103.27 \\
\hline & $\begin{array}{l}\text { SA at } 200 \\
\text { ppm }\end{array}$ & 83.74 & 83.46 & 64.99 & 56.79 & 18.75 & 26.67 & 96.74 & 92.31 \\
\hline & $\begin{array}{l}\text { Vit. C at } 300 \\
\text { ppm }\end{array}$ & 83.54 & 83.78 & 64.17 & 58.56 & 19.37 & 25.22 & 87.67 & 90.94 \\
\hline \multicolumn{2}{|c|}{ LSD at 0.05 level } & 0.80 & 1.18 & 0.81 & 0.65 & 0.70 & 0.77 & 2.96 & 3.55 \\
\hline
\end{tabular}

Table (7): Effect of irrigation water quantity, some antioxidants foliar application on yield and its components and water use efficiency during 2017 and 2018 seasons

\begin{tabular}{|c|c|c|c|c|c|c|c|c|c|c|}
\hline \multirow{3}{*}{ Characters } & \multicolumn{2}{|c|}{$\begin{array}{l}\text { Average pod } \\
\text { number } I \\
\text { plant }\end{array}$} & \multicolumn{2}{|c|}{$\begin{array}{c}\text { Average pod } \\
\text { weight }(\mathrm{g})\end{array}$} & \multicolumn{2}{|c|}{$\begin{array}{l}\text { Yield / plant } \\
\text { (g) }\end{array}$} & \multicolumn{2}{|c|}{$\begin{array}{c}\text { Total yield } \\
\text { (ton/fed.) }\end{array}$} & \multicolumn{2}{|c|}{$\begin{array}{c}\text { Water use } \\
\text { efficiency } \\
\text { (kg/m } / \mathrm{m}^{3} \text { water) }\end{array}$} \\
\hline & \begin{tabular}{|l|}
2017 \\
season
\end{tabular} & $\begin{array}{l}2018 \\
\text { season }\end{array}$ & $\begin{array}{c}2017 \\
\text { season }\end{array}$ & $\begin{array}{c}2018 \\
\text { season }\end{array}$ & \begin{tabular}{|c|}
2017 \\
season
\end{tabular} & 2 & 20 & $\begin{array}{l}2018 \\
\text { season }\end{array}$ & $\begin{array}{c}2017 \\
\text { season }\end{array}$ & $\begin{array}{c}2018 \\
\text { season }\end{array}$ \\
\hline & \multicolumn{10}{|c|}{ Effect of irrigation water quantity } \\
\hline 1000 (m³/fed.) & 8.61 & 8.25 & 5.43 & 6.11 & \begin{tabular}{|l|}
47.28 \\
\end{tabular} & \begin{tabular}{|l|}
50.61 \\
\end{tabular} & 2.118 & 2.267 & 2.118 & 2.267 \\
\hline 1500 (m³/fed.) & 9.53 & 10.07 & 6.12 & 6.80 & 58.58 & 68.71 & 2.624 & 3.078 & 1.749 & 2.052 \\
\hline 2000 (m³/fed.) & 0.85 & 1095 & 6.12 & $7 ? 2$ & 69.85 & 7923 & 3129 & 3.550 & 1.565 & 1775 \\
\hline \multirow[t]{2}{*}{$\begin{array}{c}\text { LSD at } 0.05 \\
\text { level }\end{array}$} & .54 & 0.53 & 0 & 0.13 & 1.74 & 2.18 & 0.218 & .305 & 0.189 & $\cdot, 1 \vee 4$ \\
\hline & \multicolumn{10}{|c|}{ Effect of some antioxidants } \\
\hline $\begin{array}{l}\text { nsprayed } \\
\text { ontrol) }\end{array}$ & & & & & 48.49 & 56.90 & & .549 & 1.467 & 1.733 \\
\hline SA at $200 \mathrm{ppm}$ & 10.37 & .30 & 5 & 7 & 67.28 & 5.17 & 3.0 & 3.368 & 2.113 & 2.327 \\
\hline $\begin{array}{l}\text { Vit. C at } 300 \\
\text { ppm }\end{array}$ & 9.89 & & & 6.70 & 59.94 & 6.48 & 2.000 & .978 & 1.852 & 2.033 \\
\hline $\begin{array}{l}\text { LSD at } 0.05 \\
\text { evel }\end{array}$ & 0.43 & 0.42 & 0.08 & 0.10 & 1.36 & 1.71 & 0.171 & 0.239 & 0.171 & $\cdot, 1 \leqslant V$ \\
\hline
\end{tabular}


Average pod weight, number of pods/ plant, yield/ plant and total yield per fed were significantly increased with increasing water quantity up to the highest rate $\left(2000 \mathrm{~m}^{3} / \mathrm{fed}\right.$.). In both seasons. While the highest value of water use efficiency $(2.118$ and $2.267 \mathrm{~kg}$ podsl $\mathrm{m}^{3}$ water) was recorded with $1000 \mathrm{~m}^{3} / \mathrm{fed}$. followed by $\left(1.749\right.$ and $2.052 \mathrm{~kg}$ pods $/ \mathrm{m}^{3}$ water) with water quantity at $1500 \mathrm{~m}^{3} / \mathrm{fad}$. and then water $(1.565$ and $1.775 \mathrm{~kg}$ pods $/ \mathrm{m}^{3}$ water) with $2000 \mathrm{~m}^{3} / \mathrm{fed}$. in the $1^{\text {st }}$ and $2^{\text {nd }}$ seasons, respectively.

The relative increases in total yield were about (47.73 and $56.59 \%)$ for 2000 $\mathrm{m}^{3} / \mathrm{fad}$., and (23.89 and $\left.45.32 \%\right)$ for 1500 $\mathrm{m}^{3}$ water/fad. over than the treatment (1000 $\mathrm{m}^{3}$ water/fed.) in the $1^{\text {st }}$ and $2^{\text {nd }}$ seasons, respectively.

The increases in total yield might be due to the increase in average pod weight (Table 7). Also, this might be due to the favorable effect of higher amounts of irrigation water on vegetative growth (Table 1) and photosynthetic pigments (Table 3).

These results were found to be agree with those reported by Marzouk et al. (2016), and Vidyashree et al. (2018). They found that increasing irrigation levels up to the highest rate increasing yield and its components of snap bean. Regarding water use efficiency, Saleh et al. (2018) showed that WUE progressively increased when decreasing the water application from 100 to $60 \%$ of ET.

As regards the effect of antioxidants foliar application, it was evident from the data in Table 7 that spraying snap bean plants with SA or Vit. C had a significant effects on yield and its components and water use efficiency in both seasons. Spraying plants with SA recorded the maximum increment of average pod weight, number of pods/ plant, yield/ plant and total yield per fed. as well as water use efficiency in both seasons.

The relative increases in total yield as the results of spraying plants with SA were about (38.70 and $32.13 \%$ ). and (23.56 and 16.83\%) for Vit C. over unsprayed plants in the $1^{\text {st }}$ and $2^{\text {nd }}$ seasons, respectively.

The increase in total yield might be due to the increase in average pod weight (Table 7). Also, this might be due to the favorable effect of SA or Vit. C.on vegetative growth (Table 1 ) as previously explained and leaf pigments (Table 2). These results agreed with the results reported by Amer (2004), Kmal et al. (2006) on snap bean, Shafeek et al. (2014) and Shokr et al. (2014) on snap bean regarding SA and Hamaiel et al. (2016) on snap bean and Rasheed (2018) on broad bean concerning Vit.C.

It is clear from the data in Table 8 that, irrigation of snap bean plants with 2000 $\mathrm{m}^{3}$ water /fed., and spraying plants with SA recorded the highest values of average pod weight, yield I plant and total yield/fed., while, irrigation with 1000 $\mathrm{m}^{3}$ waterl fed., combined with SA increased water use efficiency ( 2.692 and $2.731 \mathrm{~kg}$ green pods $/ \mathrm{m}^{3}$ water) in the $1^{\text {st }}$ and $2^{\text {nd }}$ seasons, respectively.

The increases in total yield/fed., were about 143.39 and $111.75 \%$ for the interactions between water quantity at $2000 \mathrm{~m}^{3} / \mathrm{fad}$., and spraying plants with SA over the interactions between water quantity of $1000 \mathrm{~m}^{3} / \mathrm{fed}$. and unsprayed plants in the $1^{\text {st }}$ and $2^{\text {nd }}$ seasons, respectively.

\section{Pod Quality}

Data in Table 9 show that total fiber (\%), total soluble solids (\%), total carbohydrates and vitamin $\mathrm{C}$ contents in pod tissues were significantly affected by 
irrigation water quantity in both seasons. Irrigation water quantity at $2000 \mathrm{~m}^{3} / \mathrm{fed}$. significantly increased total soluble solids (\%), total carbohydrates and vitamin $C$ contents and decreased total fiber (\%) in pod tissues.

These results agreed with Saleh et al. (2018) on snap bean, they showed that the highest volume of irrigation water $(100 \%$ of $E T)$ resulted in the highest contents of total protein, total sugar, Vit. $C$ and lowest values of fiber contents in green pods.

Respecting to the effect of antioxidants on pod quality, it was observed from the pervious table that spraying snap bean plants with SA or Vit.C had significant effect on all traits of pod quality in both seasons. Spraying plants with SA increased TSS, while spraying wit Vit. C increased total carbohydrates and Vit. $C$ contents in pods, on the other hand unsprayed treatment increased total fiber (\%) in pods in both seasons. Results are harmony with those reported by Shokr et al (2014) on snap bean regarding SA and Hamaiel et al. (2016) on snap bean as for Vit. C

Table (8): Effect of interaction between irrigation water quantity and some antioxidants foliar application on yield and its components and water use efficiency of snap bean during 2017 and 2018 seasons

\begin{tabular}{|c|c|c|c|c|c|c|c|c|c|c|c|}
\hline & \multicolumn{2}{|c|}{$\begin{array}{l}\text { Average pod } \\
\text { number } I \\
\text { plant }\end{array}$} & \multicolumn{2}{|c|}{$\begin{array}{l}\text { Average pod } \\
\text { weight }(\mathrm{g})\end{array}$} & \multicolumn{2}{|c|}{$\begin{array}{l}\text { Yield / plant } \\
\text { (g) }\end{array}$} & \multicolumn{2}{|c|}{$\begin{array}{l}\text { Total yield } \\
\text { (ton/fed.) }\end{array}$} & \multicolumn{2}{|c|}{$\begin{array}{c}\text { Water use } \\
\text { efficiency } \\
\left(\mathrm{kg} / \mathrm{m}^{3}\right. \\
\text { water) }\end{array}$} \\
\hline & & $\begin{array}{l}2017 \\
\text { season }\end{array}$ & $\begin{array}{c}2018 \\
\text { season }\end{array}$ & $\begin{array}{c}2017 \\
\text { season }\end{array}$ & $\begin{array}{c}2018 \\
\text { season }\end{array}$ & $\begin{array}{c}2017 \\
\text { season }\end{array}$ & $\begin{array}{l}2018 \\
\text { season }\end{array}$ & \begin{tabular}{|l|}
2017 \\
season
\end{tabular} & \begin{tabular}{|l|}
2018 \\
season
\end{tabular} & $\begin{array}{l}2017 \\
\text { season }\end{array}$ & $\begin{array}{l}2018 \\
\text { season }\end{array}$ \\
\hline \multirow{3}{*}{$\begin{array}{c}1000 \\
\mathrm{~m}^{3} / \mathrm{fed}\end{array}$} & $\begin{array}{c}\text { Unsprayed } \\
\text { ( control) }\end{array}$ & 7.36 & 7.86 & 4.75 & 5.34 & 34.96 & 41.97 & 1.566 & 1.880 & 1.566 & 1.880 \\
\hline & $\begin{array}{c}\text { SA at } 200 \\
\text { ppm }\end{array}$ & 9.6 & 8.66 & 6.26 & 7.04 & 60.10 & 60.97 & 2.692 & 2.731 & 2.692 & 2.731 \\
\hline & $\begin{array}{l}\text { Vit. C at } \\
300 \text { ppm }\end{array}$ & 8.86 & 8.23 & 5.28 & 5.94 & 46.78 & 48.89 & 2.096 & 2.190 & 2.096 & 2.190 \\
\hline \multirow{3}{*}{$\begin{array}{c}1500 \\
\mathrm{~m}^{3} / \mathrm{fed}\end{array}$} & $\begin{array}{c}\text { Unsprayed } \\
\text { ( control) }\end{array}$ & 8.8 & 9.53 & 5.46 & 6.14 & 48.05 & 58.51 & 2.153 & 2.621 & 1.435 & 1.747 \\
\hline & $\begin{array}{c}\text { SA at } 200 \\
\text { ppm }\end{array}$ & 10 & 10.63 & 6.33 & 7.12 & 63.30 & 75.69 & 2.836 & 3.391 & 1.891 & 2.261 \\
\hline & $\begin{array}{l}\text { Vit. C at } \\
300 \text { ppm }\end{array}$ & 9.8 & 10.06 & 6.57 & 7.15 & 64.39 & 71.93 & 2.884 & 3.222 & 1.923 & 2.148 \\
\hline \multirow{3}{*}{$\begin{array}{c}2000 \\
\mathrm{~m}^{3} / \mathrm{fed}\end{array}$} & $\begin{array}{c}\text { Unsprayed } \\
\text { ( control) }\end{array}$ & 10.06 & 10.06 & 6.21 & 6.98 & 62.47 & 70.22 & 2.799 & 3.146 & 1.400 & 1.573 \\
\hline & $\begin{array}{l}\text { SA at } 200 \\
\text { ppm }\end{array}$ & 11.5 & 11.6 & 6.82 & 7.66 & 78.43 & 88.86 & 3.514 & 3.981 & 1.757 & 1.991 \\
\hline & $\begin{array}{l}\text { Vit. C at } \\
300 \text { ppm }\end{array}$ & 11 & 11.2 & 6.24 & 7.02 & 68.64 & 78.62 & 3.075 & 3.522 & 1.538 & 1.761 \\
\hline \multicolumn{2}{|c|}{ LSD at 0.05 level } & 0.74 & 0.72 & 0.15 & 0.18 & 2.37 & 2.96 & 0.296 & 0.415 & 0.300 & 0.259 \\
\hline
\end{tabular}


Table (9): Effect of irrigation water quantity, some antioxidants foliar application on pod quality of snap bean during 2017 and 2018 seasons

\begin{tabular}{|c|c|c|c|c|c|c|c|c|}
\hline \multirow{3}{*}{ Characters } & \multicolumn{2}{|c|}{ Total fiber (\%) } & \multicolumn{2}{|c|}{ TSS } & \multicolumn{2}{|c|}{$\begin{array}{c}\text { Total } \\
\text { carbohydrates } \\
\text { (\%) }\end{array}$} & \multicolumn{2}{|c|}{$\begin{array}{c}\text { Vit C ( mg/100 g } \\
\text { FW) }\end{array}$} \\
\hline & $\begin{array}{l}2017 \\
\text { season }\end{array}$ & $\begin{array}{c}2018 \\
\text { season }\end{array}$ & $\begin{array}{l}2017 \\
\text { season }\end{array}$ & $\begin{array}{c}2018 \\
\text { season }\end{array}$ & $\begin{array}{l}2017 \\
\text { season }\end{array}$ & $\begin{array}{c}2018 \\
\text { season }\end{array}$ & $\begin{array}{l}2017 \\
\text { season }\end{array}$ & $\begin{array}{l}2018 \\
\text { season }\end{array}$ \\
\hline & \multicolumn{8}{|c|}{ Effect of irrigation water quantity } \\
\hline $\begin{array}{c}1000 \\
\left(\mathrm{~m}^{3} / \mathrm{fed} .\right)\end{array}$ & 8.46 & 9.12 & 4.62 & 4.59 & 38.09 & 41.84 & 8.68 & 8.82 \\
\hline $\begin{array}{c}1500 \\
\left.\text { ( } \mathrm{m}^{3} / \mathrm{fed} .\right)\end{array}$ & 7.74 & 8.15 & 5.09 & 5.34 & 40.16 & 44.12 & 10.25 & 10.43 \\
\hline $\begin{array}{c}2000 \\
\left(\mathrm{~m}^{3} / \mathrm{fed} .\right)\end{array}$ & 7.17 & 7.29 & 5.55 & 5.43 & 47.64 & 50.40 & 11.22 & 11.36 \\
\hline \multirow[t]{2}{*}{$\begin{array}{c}\text { LSD at } 0.05 \\
\text { level }\end{array}$} & 0.43 & 0.29 & 0.10 & 0.13 & 0.87 & 1.31 & 0.48 & 0.32 \\
\hline & \multicolumn{8}{|c|}{ Effect of some antioxidants } \\
\hline $\begin{array}{l}\text { Unsprayed } \\
\text { (control) }\end{array}$ & 8.23 & 8.64 & 4.73 & 4.68 & 39.53 & 43.47 & 9.39 & 9.53 \\
\hline $\begin{array}{l}\text { SA at } 200 \\
\text { ppm }\end{array}$ & 7.64 & 8.12 & 5.45 & 5.60 & 42.16 & 45.54 & 10.13 & 10.46 \\
\hline $\begin{array}{l}\text { Vit. C at } 300 \\
\text { ppm }\end{array}$ & 7.50 & 7.80 & 5.08 & 5.08 & 44.20 & 47.35 & 10.63 & 10.62 \\
\hline $\begin{array}{l}\text { LSD at } 0.05 \\
\text { level }\end{array}$ & 0.34 & 0.23 & 0.08 & 0.10 & 0.68 & 1.03 & 0.38 & 0.25 \\
\hline
\end{tabular}

As for the interactions effect data in Table 10 show that, the interaction treatments between water quantity and spraying with antioxidants had significant effect on pod quality, in both seasons. TSS, had the highest values with the interactions treatment between water quantity at $2000 \mathrm{~m}^{3} / \mathrm{fed}$., and spraying plants with SA, total carbohydrates and Vit. $C$ were the maximum with $2000 \mathrm{~m}^{3} / \mathrm{fed}$. and spraying with Vit. C, while total fiber (\%) was the highest by the interactions between 1000 $\mathrm{m}^{3}$ water/fed., without antioxidants in both season.

Conclusively, at similar experimental conditions it could be concluded that, the irrigation of snap bean plants with $2000 \mathrm{~m}^{3} / \mathrm{fed}$., and spraying with SA at 200 ppm was the proper for enhancing yield and improved green pod quality. 
Table (10): Effect of interaction between irrigation water quantity and some antioxidants foliar application on pod quality of snap bean during 2017 and 2018 seasons.

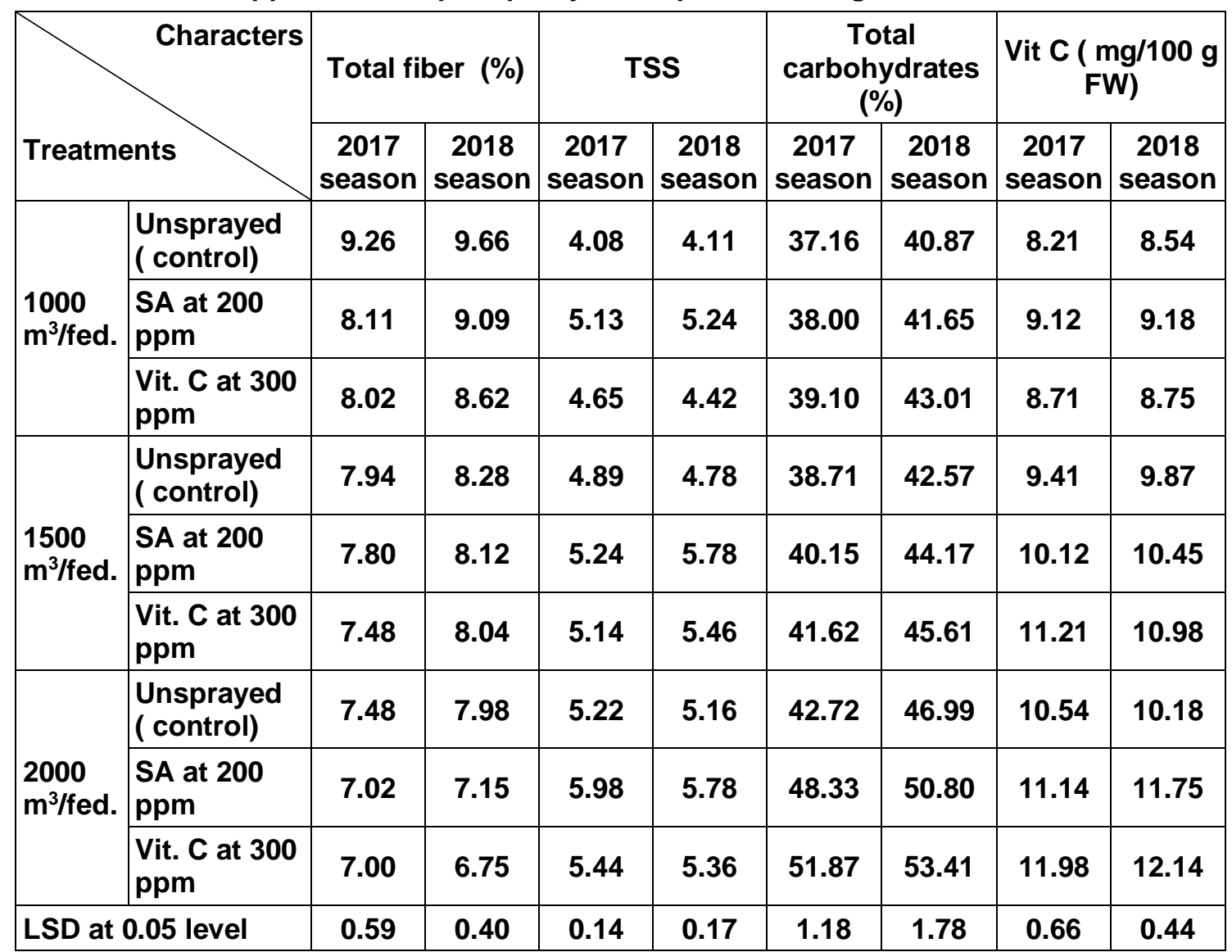

\section{REFERENCES}

A.O.A.C. (1990). Association of Official Agricultural Chemists. Methods of Analysis, 15th edition, Washington, D.C.USA.

Abbas, M.F., A. Jerry and H. Abd ElEmam (2014). Effect of salicylic acid and ascorbic acid and method of application on flowering and green yield of broad bean (Vicia faba L.) plants, Basrah J. Agric. Sci., 27(1): 3443.

Abdel-Ati, Y.Y., S.H. Gad El-Hak, A. A. Galal and Y. M. M. Moustafa (2000). Effect of some antioxidant compounds on some horticultural characters of four new $F_{1}$ hybrids of tomato. J. Agric.Sci. Mans. Univ,. 25: 1673-1692.
Abdel-Mawgoud, A.M.R. (2006). Growth, yield and quality of green bean (Phaseolus vulgaris L.) in response to irrigation and compost applications. $J$. Appl. Sci. Res., 2 (7): 443-450.

AL-Amry N. J. and M.M. Mohammed (2017). Influence of adding ascorbic acid and yeast on growth and yield and Rhizobium of snap bean (Phaseolus vulgaris L.) under irrigation with saline water. IOSR J. Agric. Veter. Sci., 10 (10): 23-28.

Amer, A.H., M. El - Desuki, Omaima M. Sawan and A.M. Ibrahim (2002). Potentiality of some snap bean (Phaseolus vulgaris L.) varieties under different irrigation levels at Shark EI Owinat Region. Egypt. J. Appl. Sci., 17(1): 327-345. 
Amer, S.S.A. (2004). Growth, green pods yield and seeds yield of common bean (Phaseolus vulgaris L.) as affected by active dry yeast, salicylic acid and their interaction. J. Agric. Sci., Mansoura Univ., 29(3): 1407-1422.

Azooz, M. and M. Al-Fredan (2009). The inductive role of vitamin $C$ and its mode of application on growth, water status, antioxidant enzyme activities and protein patterns of Vicia faba $L$. cv. Hassawi grown under seawater irrigation. Amer J. Plant Physiol., 4(1): 38-51.

Banon, S.J., J. Ochoa, J.A. Franco, J.J. Alarcon and M.J. Sanchez-Blanco (2006). Hardening of oleander seedlings by deficit irrigation and low air humidity. Environ. And Exp. Bot., 56: 36-43.

Barker, D.J., C.Y. Sullivan and L.E. Moser (1993). Water deficit effect on osmotic potential, cell wall elasticity and proline in five forage grasses. Agron. J., 85:270-275.

Bates, L. S. (1973). Rapid determination of proline for water stress studies. Plant and Soil 39 : 205-207.

Begg, J.E. and N. C. Turner (1976). Crop water deficits . Advances in Agron. 28 , pp.189.

Burguieres, E., P. McCue, Y. Kwon and K. Shetty (2007). Effect of vitamin C and folic acid on seed vigour response and phenolic-linked antioxidant activity. Bioresour Technol., 98(7):1393-1404.

Dubois, M., K. A. Gilles, J. Hamillon, P. A. Rebers and F. Smith (1956). Colorimeteric methods for determination of sugars and related substances. Anal. Chem., 28:350.

Elade, Y. (1992). The use of antioxidants to control gray mould (Botrytis cinerea) and white mould (Sclerotinia scleotiorum) in various crops. Plant Pathol., 141: 417-426.
El-Noemani, A., A.A., Aboellil and O.M. Dewedar (2015). Influence of irrigation systems and water treatments on growth, yield, quality and water use efficiency of bean (Phaseolus vulgaris L.) plants. Int.J. ChemTech Res., 8(12): 248-258.

El-Saadony, F.M., Dalia A.S. Nawar and H.G. Zyada (2017). Effect of foliar application with salicylic acid, garlic extract and proline on growth, yield and leaf anatomy of pea (Pisum sativum L.) grown under drought stress. Middle East J. Appl. Sci., 7(3): 633-650.

El-Shraiy, A.M. and A.M. Hegazi (2009). Effect of acetylsalicylic acid, indole-3buytric acid and gibberellic acid on plant growth and yield of pea (Pisum sativum L.). Aust. J. Basic and Appl. Sci.,3 (4): 3514-3523.

El-Tayeb, M.A. (2006). Differential response of two Vicia faba cultivars to drought: growth, pigments, lipid peroxidation, organic solutes, catalase and peroxidase activity. Acta Agronomica Hungarica, 54 (1): 25-37.

El-Tohamy, W.A., H.M. El-Abagy, M.A. Badr and N. Gruda (2013). Drought tolerance and water status of bean plants (Phaseolus vulgaris L.) as affected by citric acid application. J. Appl. Bot. Food Qual., 86: 212-216.

Gosev, N. A. (1960). Some methods in studying plant water relations. Leningrad Acad. of Science, U.S.S.R. (C.F. Hussein, M.H., Ph.D. Thesis, Fac. Agric., Ain Shams Univ., Cairo, Egypt,1973).

Hamaiel, A. F., M. S. Hamada, M. M. B. Shokr and E.M. M. Abd-Elrhem (2016). response of some snap bean cultivars to foliar application with some antioxidant substances for increasing productivity and quality under local environments at early summer season. J. Plant Production, Mansoura Univ., 7(11): 1221 - 1231. 
Hayat, S., S. A. Hasan, Q. Hayat, M. Irfan and A. Ahmad (2010). Effect of salicylic acid on net photosynthetic rate, chlorophyll fluorescence, and antioxidant enzymes in Vigna radiata plants exposed to temperature and salinity stresses. Plant Stress, 4: 6271.

Herbinger, K., M., A. Tausz, G. Wonisch, A. Sorger and D. Grill (2002). Complex interactive effects of drought and ozone stress on the antioxidant defense systems of two wheat cultivars. Plant Physiol. Biochem., 40: 691-696.

Kelly, I.D. and F.A. Bliss (1975). Heritability estimates of percentage seed protein and available methionine and correlations with yield in dry bean. Crop Sci., 15: 753-757.

Khafaga, H.S., A. H. Raeefa, M.M. Hala and S.A. Ala (2009). Response of two faba bean cultivars to application of certain growth regulators under salinity stress condition at siwa oasis. 1- Growth traits, yield and yield components. $4^{\text {th }}$ Conference on Recent Tech. in Agric.

Khan, A.Z., P. Shah, S.K. Khalil and F.H. Taj (2003). Influence of planting date and plant density on morphological traits of determinate and indeterminate soybean cultivars under temperate environment. J. Agron., 2: 146-152.

Khan, T.A., M. Mazid and F. Mohammad (2011). A review of ascorbic acid potentialities against oxidative stress induced in plants. J. Agrobiol., 28 (2): 97-111.

Kmal, A.K., E.A. Amen and A.M. Al-Said (2006). Response of snap bean (Phaseolus vulgaris L.) to some salicylic acid drevativs and selenium under high temperature stress. J. Agric. Sci., Mansoura Univ., 31(11): 7321-7328.
Lancher, W. (1993). Physiological Plant Ecology. Ecophysiology and Stress Physiology of Functional Groups. $3^{\text {rd }}$ Ed., springier press. Berlin, New York, London, Paris, Tokyo.

Marzouk, N. M., R.E., Abdelraouf, S.R. Salman and M. M. H. Abd El Baky (2016). Effect of water stress on yield and quality traits of different snap bean varieties grown in an arid environment. Middle East J. Agric. Res., 5(4): 629-635.

Maynard, A.J. (1970). Methods in food analysis. Academic Press New York, London, $176 \mathrm{pp}$.

Murtaza, G., R. Asghar, S. Ahmad and S. Abdul Majid (2007). The yield and yield components of pea (Pisum sativum L.) as influenced by salicylic acid. Pak. J. Bot., 39(2): 551-559.

Noctor, G. and C.H. Foyer (1998). Ascorbat and glutathione: keeping active oxygen under control. Ann. Rev. Plant Physiol. Plant Mol. Biol.,49:249-279.

Novabpour, S., K. Morris, R. Allen, E. Harrison and V. Wollaston (2003). Expression of senescence enhanced genes in response to oxidative stress. J. Experim. Botany, 54: 2285-2292.

Rady, M. M. (2006). Efficiency of growth and productivity of sunflower plants as affected by ascorbic acid under saline reclaimed soil conditions. 2nd conf. on farm integrated pest Managemnt, Fac. Agric., Fayoum Univ., Egypt, pp: 186-200.

Rasheed, S. M. S. (2018). Effect of Salicylic and Ascorbic acid on Growth, Green yield of two Broad bean Cultivars (Vicia faba L.). ZJPAS: (5): 71-88

Saleh, S., G. Liu, M. Liu, Y. Ji, H. He, ID and N. Gruda (2018). Effect of irrigation on growth, yield, and chemical composition of two green bean cultivars. Horticulturae, 4(3): 110. 
Sazen, S.M., A. Yazar, A. Akyildiz, H.Y. Dasgan and B. Gencel (2008). Yield and quality response of drip irrigated green beans under full and deficit irrigation. Sci. Hortic., 117: 95-102.

Shadded, L. M. A., A. F. Radi, A. M. AbdelRahman and M. M. Azooz (1990). Response of seeds of Lupinus termis and Vicia faba to the interactive effect of salinity and ascorbic acid on pyridoxines. Plant and soil, 122: 177183.

Shafeek, M.R., Y.I. Helmy, 1A.A. Ahmed and Magda A.F. Shalaby (2014). Productivity of snap bean plants by spraying of some antioxidants materials under sandy soil conditions in plastic house. Middle East J. Agric. Res., 3(1): 100-105.

Shokr, M.M.B., Elsaid M. Elsaid and M.R. Shafeek (2014). Effect of some stimulative substances as foliar applications on snap bean (Phaseolus vulgaris L.) productivity under milder thermo-stress of local summer season. Middle East J. Appl. Sci., 4(2): 175-180.

Smesrud, J., B. Mansour, M. Hess and J. Selker (1997). Oregon state university western oregon green bean irrigation Guide, 541. Department of Bioresource Engineering, 116 Gilmore Hall, Corvallis, pp. 737-6304 (or 97331-3906).

Snedecor, G.W. and W.G. Cochran (1980). Statistical Methods. $7^{\text {th }}$ ed. Iowa State Univ., Press, Ames., lowa, U.S.A.
Sreenivasulu, N., B. Grimm, U. Wobus and W. Weschke (2000). Differential response of antioxidant compound to salinity stress in salt-tolerant and saltsensitive seedlings of foxtail millet (Setaria italica). Physiol. Plant., 109: 435-440.

Stewart, C.R. (1977). Inhibition of proline oxidation by water stress. Plant Physiol., 59 : 930-932.

Thomson, T., G.S. Patel, J.B. Thakar and K.S. Pandya (2017). Effect of foliar application of acetyl salicylic acid and ascorbic acid on growth and yield of Garden Pea (Pisum sativum L.) cv. Bonneville. Int. J. Curr. Microbiol. App.Sci. 6(6): 1971-1976.

Vidyashree, B. M., K. Kandpal, M. Nemichandrappa and B.S. Polisgowdar (2018). Role of colour plastic mulching and drip irrigation levels on water saving and economics of french bean (Phaseolus vulgaris L.). Int. J. Curr. Microbiol. App. Sci 7(8): 3246-3250.

Wettestein, D. (1957). Chlorophyll. Lethale under submikroskopische formwechsel der plastiden. Exptl. Cell Reso. 12: 427-506.

Younis, M. E., M.N.A. Hasaneen and A. E. S. Kazamel (2010). Exogenously applied ascorbic acid ameliorates detrimental effects of $\mathrm{NaCl}$ and mannitol stress in Vicia faba seedlings. Protoplasma, 239 (1-4): 3948. 
تأثير كميات مياه الرى وبعض مضادات الأكسده على المحصول وبعض القياسات

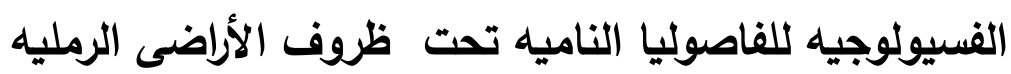

\author{
محمد محمد عبد اللطيف رمضان
}

معهt بحوث البساتين - مركز البحوث الزراعيه

الملخص العربى

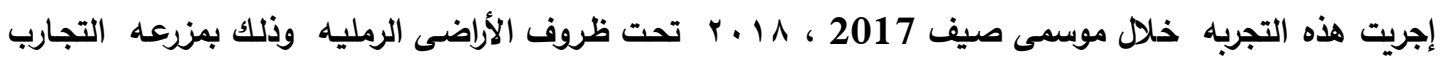

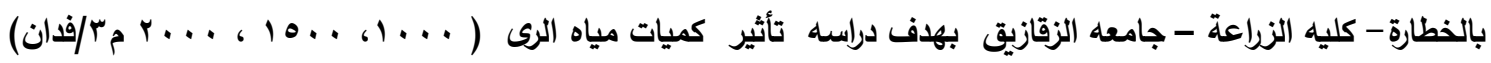

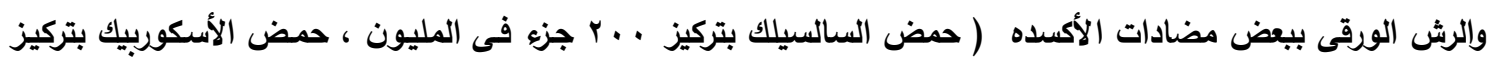

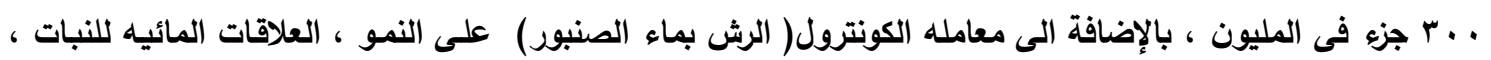

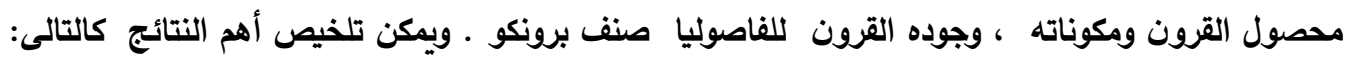

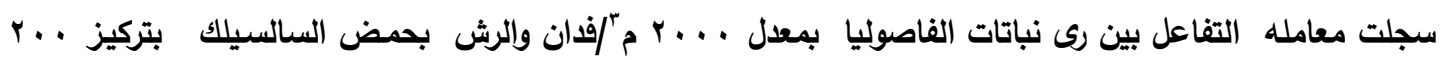

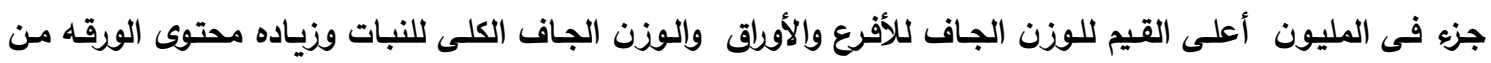

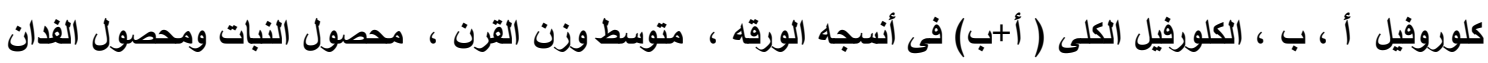

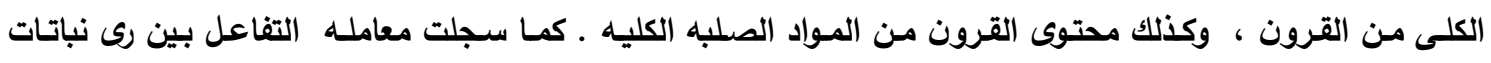

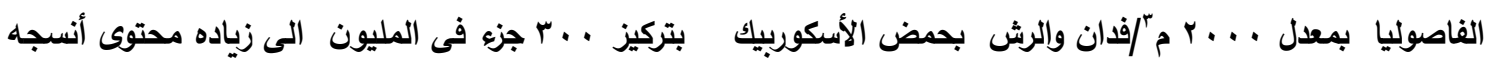

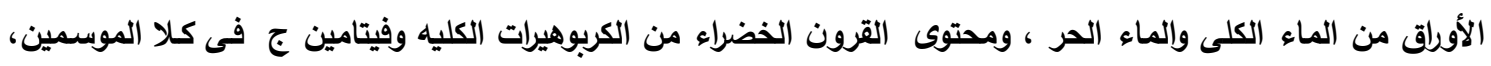

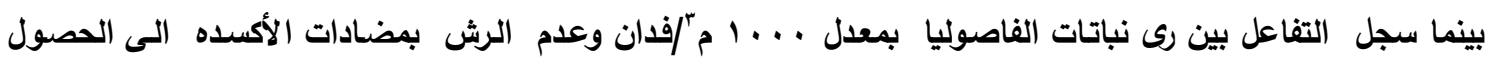

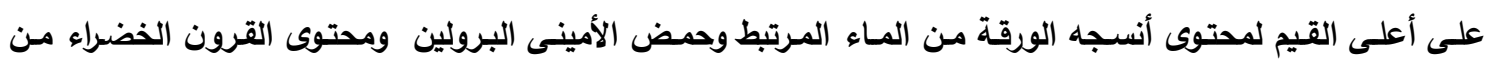

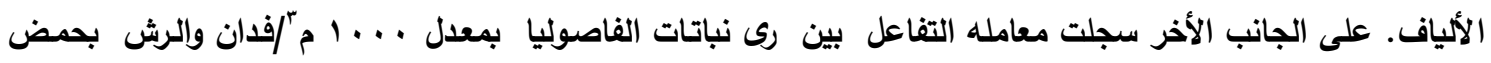

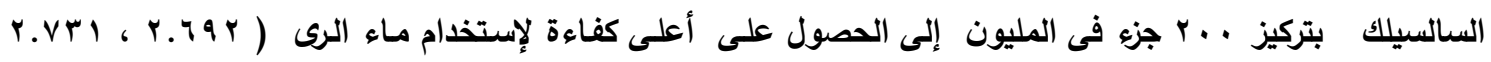
كجم/مَّ ماء ) خلا الموسم الأول والثانى على التوالى.

السادة المحكمين

أ.د/ السيد محمد أبوالخير معهة بحوث البساتين - مركز البحوث الززاعية - الجيزة

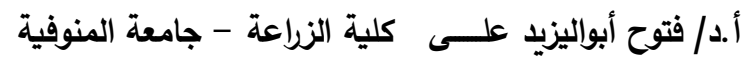


